\title{
Plant Parasitic Nematodes Associated with Olive in Algeria
}

\author{
M. BELAHMAR ${ }^{1}$, F. ELKFEL ${ }^{1}$, M. MIHOUB ${ }^{3}, \mathrm{~S}_{\text {ABDEWAHAB }}^{3}$, \\ M. MATEILLE ${ }^{2}$ and S. SELLAMI ${ }^{3 *}$ \\ ${ }^{1}$ University of Science and Technology, Houari Boumedienne, Algiers, Algeria \\ ${ }^{2}$ Institute of Research and Developement (IRD), Montpellier, France \\ ${ }^{3}$ Department of Botany, High National School Agronomy El Harrach, Algiers, Algeria
}

(Received: 25 March 2015; accepted: 13 May 2015)

\begin{abstract}
Surveys were conducted during 2010-2013 in olive growing areas of south and north of Algeria to identify plant parasitic nematodes associated with this crop. Sixteen genera of plant-parasitic nematodes were identified. Among them four are considered as having economic importance for olive. Among these the endoparasites Pratylenchus spp. were detected in the majority of the sampled areas and were the most frequent. Meloidogyne spp. were also present in some areas. Helicotylenchus spp. were present with a high frequency in almost all surveyed sites. Among the ectoparasites, only Xiphinema spp. have potential to damage olive. Other nematodes of less importance were poorly represented. Nematode densities varied according to taxa identified and areas surveyed. Excepted Pratylenchus spp. and Helicotylenchus spp., the others taxa are reported for the first time on olive in Algeria.
\end{abstract}

Keywords: olive, plant parasitic nematodes, nursery, orchard.

In Algeria, olive crop is one of the most important revenue for the economy of the rural population. The crop covers an area of 312,000 hectares planted with 34 million trees, resulting in an annual production of about 193,000 tons of table olives and 400,000 tons of oil olive in 2011 (MADR, 2011). Revitalized by the National Plan for Agricultural and Rural Development (PNDAR) in 2000, the Algerian olive cultivation has increased from 165,000 ha in 1999 to 312,000 ha in 2011, with the eastern regions and centre of the country being the most important olive-growing areas, representing $23 \%$ and $49 \%$, respectively, of the national olive orchard. Cultivation of olive has gained particular interest in recent years nationwide. Besides, the crops have socio-economic and environmental value and olives, especially olive oil, have peculiar nutritional qualities (COI, 2009). According to preliminary surveys carried out by staff of the Plant Protection Institute and farmers complaints, olive plants are prone to diseases and pests (Bennai and Hamadache, 2012). Nico et al. (2002) and Castillo et al., (1999, 2010) reported that plant-parasitic nematodes can be very damaging to olive crop. Among these nematodes Pratylenchus spp. (root lesion nematodes) and Meloidogyne spp. (root-knot nematodes) must be mentioned. Other nematodes having potential to damage olive are Heterodera mediterranea

\footnotetext{
* Corresponding author; e-mail: s.sellami@hotmail.fr
} 
(cyst nematodes), Rotylenchulus spp. (reniform nematodes) and Helicotylenchus spp. (spiral nematodes).

Unfortunately, data on nematodes associated with olive trees are not available in Algeria, except the report on Pratylenchus spp. by Troccoli et al. (1992). Information on plant parasitic nematodes of olive in Algeria is necessary to limit yield losses. Therefore, our objective was to identify plant-parasitic nematodes associated with olive threes in some olive production areas.

\section{Materials and Methods}

The survey was conducted in the main olive-growing regions of western (Mascara), central (Boumerdes, Blida) and eastern (Bejaia), in the north and south (Biskra, El Oued and Laghouat) regions of Algeria during 2010-2013 (Fig. 1). The characteristics of the surveyed areas are reported in Table 1. The soil samples were collected with an auger from the rhizosphere of both olive orchards and nurseries, between 20 and $30 \mathrm{~cm}$ deep. Each soil sample was composite of several soil cores for a total of $1.5 \mathrm{~kg}$. To extract vermiform nematodes, the soil samples were processed according to the Baermann's funnel method as modified by Dalmasso (1966). The identification of the nematodes to genus level was based on the morphological characters as observed after fixation according to De Grisse (1969). Nematodes were counted using Petri dishes divided in different sectors, under a binocular stereoscope. The frequency was determined according the formula:

Frequency $=$ Number of samples containing a species / number of samples collected.

Table 1

Geo-ecological description of the study sites

\begin{tabular}{|c|c|c|c|c|c|c|}
\hline Localities & Bioclimatic & $\begin{array}{c}\text { Average } \\
\text { annual } \\
\text { rainfall } \\
(\mathrm{mm})\end{array}$ & $\begin{array}{l}\text { Average } \\
\text { tempe- } \\
\text { ratures } \\
{ }^{\circ} \mathrm{C}\end{array}$ & Longitude & Latitude & Soil texture \\
\hline \multicolumn{7}{|c|}{ North of country } \\
\hline Blida & Subhumid & 791 & 17.9 & $2^{\circ} 50^{\prime} 00^{\prime \prime}$ East & $36^{\circ} 29^{\prime} 00^{\prime \prime}$ North & Clay-loam \\
\hline Boumerdes & Humid & 739 & 18 & $3^{\circ} 28^{\prime} 0^{\prime \prime}$ East & $36^{\circ} 46^{\prime} 0^{\prime \prime}$ North & Clay-loam \\
\hline Bejaia & $\begin{array}{l}\text { Subhumid } \\
\text { to humid }\end{array}$ & 839 & 17.6 & $5^{\circ} 04^{\prime} 00^{\prime \prime}$ East & $36^{\circ} 45^{\prime} 00^{\prime \prime}$ North & Clay-loam \\
\hline Mascara & Semi-arid & 486 & 16.7 & $0^{\circ} 08^{\prime} 24^{\prime \prime}$ East & $35^{\circ} 23^{\prime} 47^{\prime \prime}$ North & Sandy \\
\hline \multicolumn{7}{|c|}{ South of country } \\
\hline Biskra & Hot, dry desert & 141 & 21.8 & $5^{\circ} 0^{\prime} 0^{\prime \prime}$ East & $34^{\circ} 0^{\prime} 0^{\prime \prime}$ North & Sandy-loam \\
\hline El Oued & Desert & 74 & 21.8 & $6^{\circ} 52^{\prime} 03^{\prime \prime}$ East & $33^{\circ} 22^{\prime} 06^{\prime \prime}$ North & Sandy \\
\hline Laghouat & Desert & 176 & 17.4 & $2^{\circ} 51^{\prime} 54^{\prime \prime}$ East & $33^{\circ} 47^{\prime} 59^{\prime \prime}$ North & Loam-sandy \\
\hline
\end{tabular}




\section{Results and Discussion}

The sites selected for sampling (Table 1) belong to very different bioclimatic zones ranging from desert floor (El Oued, Biskra, Laghouat) to semi-arid (Mascara) and humid and subhumid (Boumerdes and Blida). In the north, average temperatures and rainfall were $16.7^{\circ} \mathrm{C}$ and $18{ }^{\circ} \mathrm{C}$ and $400-839 \mathrm{~mm}$, respectively; in the south of the country (El Oued, Biskra and Laghouat), they are $17.4{ }^{\circ} \mathrm{C}$ and $21.8^{\circ} \mathrm{C}$ and from 74 to $176 \mathrm{~mm}$, respectively. The soil texture of the study sites vary greatly: at Biskra, El Oued and Laghouat it is sandy-loam to loam-sandy; in the north, it is clay except in Mascara where it is sandy.

The results showed a significant diversity of several genera of nematodes (Tables 2 and 3). Indeed, the survey revealed the presence of 16 genera of nematodes belonging to the two main order (Dorylaimida and Tylenchida): Xiphinema (Longidoridae), Meloidogyne (Meloidogynidae), Pratylenchus (Pratylenchidae), Helicotylenchus (Hoplolaimidae), Paratylenchus, Tylenchulus semipenetrans, Gracilacus (Tylenchulidae), Tylenchorhynchus (Telotylenchidae), Aphelenchoides (Aphelenchidae), Criconema, Criconemoides and Hemicriconemoides (Criconematidae), Boleodorus, Coslenchus, Tylenchus (Tylenchidae), Telotylenchus (Belonolaimidae).

Among these lists, Pratylenchus spp. are the most dangerous, frequent and dominant both in nurseries and orchards with a frequency ranging from 34.22 to $36.92 \%$, respectively, and population densities ranging from $12-60$ to $2-485$ individuals $/ 100 \mathrm{~cm}^{3}$ of soil. These migratory endoparasites are considered as quarantine pests for Algeria. Also, these nematodes have potential to cause considerable damage both to olive orchards and nurseries all over the world (Abrantes et al., 1992; Nico et al., 2002; Castillo and Vovlas, 2002).

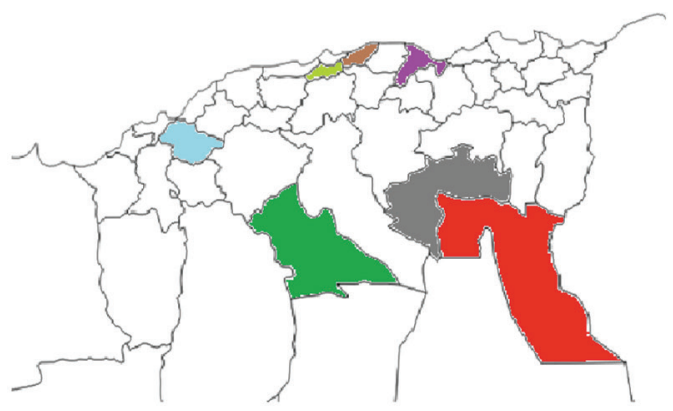

Scale:1/250000

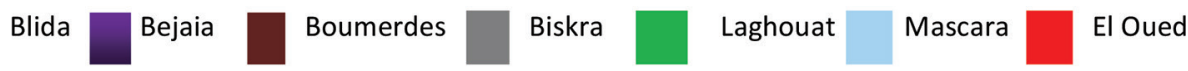

Fig. 1. Study sites where soil samples were collected during 2010-2013 
Table 2

Density and frequency of plant parasitic nematodes associated with olive orchards in Algeria

\begin{tabular}{lcc}
\hline \multicolumn{1}{c}{ Nematode genus } & Density $/ 100 \mathrm{~cm}^{3}$ & Frequency $(\%)$ \\
\hline Aphelenchoides & $3-25$ & 1.5 \\
Gracilacus & $2-14$ & 3.07 \\
Criconema & $1-13$ & 1.5 \\
Helicotylenchus & $2-441$ & 58.46 \\
Hemicriconemoides & $1-5$ & 1.5 \\
Meloidogyne & $10-102$ & 27.69 \\
Paratylenchus & $2-6$ & 7.69 \\
Pratylenchus & $2-485$ & 36.92 \\
Telotylenchus & $2-5$ & 6.11 \\
Tylenchus & $2-5$ & 9.20 \\
Tylenchorynchus & $20-110$ & 10.52 \\
Xiphinema & $1-25$ & 24.62 \\
\hline
\end{tabular}

Table 3

Density and frequency of plant parasitic nematodes associated with olive nurseries in three regions of Algeria

\begin{tabular}{lcc}
\hline \multicolumn{1}{c}{ Nematodes genus } & Density $/ 100 \mathrm{~cm}^{3}$ & Frequency $(\%)$ \\
\hline Boleodorus & $1-24$ & 2.63 \\
Coslenchus & $2-38$ & 2.63 \\
Criconemoides & $1-3$ & 2.63 \\
Helicotylenchus & $2-75$ & 23.6 \\
Meloidogyne & $33-98$ & 31.57 \\
Paratylenchus & $10-15$ & 7.89 \\
Pratylenchus & $12-60$ & 34.22 \\
Tylenchulus & $12-46$ & 13.15 \\
Tylenchorynchus & $1-13$ & 7.89 \\
Xiphinema & $1-10$ & 23.68 \\
\hline
\end{tabular}

Of the genus Pratylenchus the most common and severe species to olive are P.penetrans and P. vulnus (Nico et al., 2002; Sasanelli and D'Abbado, 2002) causing severe defoliation, leaf chlorosis, shortening of internodes, lesions and necrosis on roots (Lamberti and Baines, 1969; Nico et al., 2003).

Recently, a new species, P. olea was reported from olive roots in Tunisia and Spain (Palomares-Rius et al., 2014). In Algeria, the species P. thornei was reported in the soil rhizosphere and roots of olive tree in the Boufarik region (Blida) (Troccoli et al., 1992).

The root-knot nematodes, Meloidogyne spp. are also considered dangerous to olive and are listed in plant quarantine organisms for Algeria. They are present in the regions of Mascara and Boumerdes, both in olive nurseries and orchards with frequencies of $31.57 \%$ and $27.69 \%$ and soil population densities of 33-98 and $10-102$ juveniles $/ 100 \mathrm{~cm}^{3}$ soil, respectively. Outside Algeria, several species are reported associated to olive orchards and nurseries (Nico et al., 2002). The main species most frequently encountered are Meloid- 
ogyne arenaria, M. hapla, $M$. incognita, M. javanica, M. lusitanica and M. baetica (Castilllo et al., 2003; Nico et al., 2003). The symptoms caused by these nematodes are more severe when due to infections by $M$. javanica and $M$. arenaria followed by infections by M. incognita (Sasanelli et al., 2002; Nico et al., 2003).

Therefore, it is necessary to identify these nematodes at species level and extend the survey in other olive growing areas of Algeria, especially in the Saharan region where environmental conditions (soil texture and temperatures) are conducive to their infections.

Helicotylenchus spp. were detected in all samples of the surveyed sites with a frequency of $58.46 \%$ and soil population density in the range $2-441$ nematodes $/ 100 \mathrm{~cm}^{3}$ soil. In nurseries, they were present with a frequency of $23.6 \%$ and soil population densities of 2-75 nematodes $/ 100 \mathrm{~cm}^{3}$. Species of this genus can behave both as ectoparasites or endoparasites; they are cosmopolitan and common in cultivated and uncultivated soils (Schrec-Reis et al., 2010).

They include several species found associated with olive trees on which they cause necrosis on the roots and affect tree growth (Inserra et al., 1979). The species Helicotylenchus dihystera, reported in Egypt and Italy, reduces root growth. Helicotylenchus erythrinae, $H$. digonicus and $H$. oleae cause root necrosis, chlorosis and desiccation of the leaves have been reported from Greece and Cyprus (Philis and Siddiqui, 1976) and Jordan (Bridge, 1978 in Sasanelli, 2009; Hashim, 1979).

The genera Pratylenchus and Helicotylenchus were the most dominant and present in high soil population densities in almost all areas sampled. However, Meloidogyne sp. was only noted in the Mascara and Boumerdes regions.

Among the ectoparasites, Xiphinema sp. was also detected in the olive rhizosphere; despite it occurred at low densities, it can be damaging. It was found with frequencies of $23.68 \%$ and $24.62 \%$ and soil population densities of $1-25$ and $1-10$ nematodes per $100 \mathrm{~cm}^{3}$ in nurseries and orchards, respectively, in the Laghouat and Blida regions on the cultivar Chemlel (the olive cultivar mostly cultivated in Algeria).

According to Castillo et al. (2010), these nematodes cause severe damage to olive. The species Xiphinema diversicaudatum, $X$. elongatum and $X$. index were reported in association with root necrosis on olive whose damage were observed especially in nurseries (Ciancio and Mukerji, 2009), they also affect plant growth in Egypt (Diab and ElEraki, 1968).

Tylenchulus sp. was detected only in the nurseries of the Blida region with a frequency of $13.15 \%$ and soil population densities of $12-46$ individual $/ 100 \mathrm{~cm}^{3}$ soil. The species was identified as T. semipenetrans; its presence is probably related to the citrus vocation of this area and therefore, it would be interesting to determine the biotype, because the "citrus biotype" can reproduce on olive (Baines et al., 1974), and ascertain the pathogenicity of the nematode to olive. The variation in frequency and soil population density in different sites can be explained by differences in soil type (McSorley and Frederick, 2002) and weather conditions (Tzortzakakis and Trudgill, 2005).

The other ectoparasites encountered, Paratylenchus spp., Telotylenchus spp., Criconema spp., Criconemoides spp., Hemicriconemoide spp., Aphelenchoides spp., Gracilacus spp., Tylenchorynchus spp., Boleodorus spp., Coslenchus spp. and Tylenchus spp. were poorly represented, with frequencies lower than $10 \%$ and low soil population 
densities, and are not supposed to cause problems as their pathogenesis top olive has not been ascertained. However, the method used to extract nematodes is not the best to extract poorly motile nematodes.

The genus Criconema was detected in the rhizosphere of olive trees in Greece (Mani et al., 2014). In Portugal, only the species $C$. princeps was detected in olive (Castillo et al., 2010). Gracilacus spp. are ectoparasites with a low economic importance but have large host ranges. The species G. peratica, G. teres are reported on olive in Italy with a density of 280-360 nematodes per gram of roots (Nico et al., 2002) and Spain (Castillo et al., 2010).

These two genera of nematodes were detected in the Mascara region; they are known to be very damaging if present at high densities. However, they are poorly represented in our samples.

Tylenchorynchus spp. are very common polyphagous ectoparasites. They were reported in the majority of olive-growing countries, such as Spain, Greece, Cyprus, Turkey and Jordan (Castillo et al., 2010), but their economic importance has not been assessed. In Algeria, they were detected in all surveyed regions but at low frequencies (7.89-10.52\%). However, evidence of their pathogenicity is still lacking.

\section{Conclusion}

Finally, we feel that surveys must be extended to the other olive-growing areas of Algeria not yet explored. The extraction of the endoparasitic nematodes from the roots and the observation of them on the roots are suggested to ascertain their parasitism to olive. Also, the identification of the nematodes to species level is necessary to adopt proper control measures to limit damages caused by nematodes and their spread from nurseries to farmers'fields.

\section{Acknowledgement}

We thank Dr Greco Nicola of the Institute of Agrarian Nematology of C. N. R. Bari, Italy for the English revision of the manuscript.

\section{Literature}

Abrantes, I. M., Vovlas, N. and Santos, M. S. N. (1992): Host parasite relationships of Meloidogyne javanica et Meloidogyne lusitanica with Olea europea. Nematol. 38, 320-328.

Baines, R. C., Cameron, W. and Soost, R. K. (1974): Four biotypes of Tylenchulus semipenetrans in California identified, and their importance in the development of resistant citrus rootstocks. J. Nematol. 6, 63-66.

Bennai, M. and Hamadache, A. (2012): Protection phytosanitaire des arbres fruitiers et de la vigne. Alger, 144 p.

Castillo, P. and Vovlas, N. (2002): Factors affecting eggs hatch of Heterodera mediterranea and differential responses of olive cultivars to infestation. J. Nematol. 34, 146-150.

Castillo, P., Vovlas, N., Nico, N. and Jimenez-Diaz, R. M. (1999): Infection of olive trees by Heterodera mediterranea in orchards in southern Spain. Plant Dis. 83, 710-713. 
Castillo, P., Vovlas, N., Sergei, S. and Troccoli, A. (2003): A new root-knot nematode, Meloidogyne baetica $n$. sp. (Nematoda: Heteroderidae) parasitizing wild olive in Southern Spain. Nematol. 93, 1093-1101.

Castillo, P., Nico, A. I., Navas-Cortes, A., Landa, B. B., Jimenez-Diaz, R. M. and Vovlas, N. (2010): Plant parasitic nematodes attacking olive trees and their management. Plant Dis. 94, 148-162.

Ciancio, A. and Mukerji, K. G. (eds) (2009): Integrated Management of Fruit Crops and Forest Nematodes. Springer Science + Business Media B. V., 317 p.

COI (2009): Cinquante d'évolution du secteur oléicole, Olivae. 112, 5-12.

Dalmasso, A. (1966): Méthode simple d'extraction des nématodes du sol. Rev. Ecol. Biol. Soil 3, 473-478.

De Grisse, A. T. (1969): Redescription ou modification de quelques techniques utilisées dans l'étude des nématodes phytoparasitaires. Meded. Rijk. Landbow chappen Gent. 34, 351-369.

Diab, K. A. and El-Eraki, S. (1968): Plant-parasitic nematodes associated with olive decline in the United Arab Republic. Plant Dis. 51, 50-154.

Hashim, Z. (1979): A preliminary report on the plant parasitic nematodes in Jordan. Nematol. Medit, 7, $177-186$.

Inserra, R. N., Vovlas, N. and Morgan, G. A. (1979): Helicotylenchus oleae n. sp. and H. neopaxilli n. sp. Hoplolaimidae, two new spiral nematodes parasitic on olive trees in Italy. J. Nematol. 11, 56-62.

Lamberti, F. and Baines, R. C. (1969): Pathogenicity of four species of Meloidogyne on three varieties of olive trees. J. Nematol 1, 111-115.

MADR (2011): Statistiques du Ministère de l'Agriculture et du développement rural, 33 p.

Mani, M., Shivaraju, C. and Srinivasa Rao, M. (2014): Pests of grapewine: A worldwide list. Pest Management in Horticultural Ecosystems. Vol. 20, 170-216.

McSorley, R. and Frederick, J. J. (2002): Effect of subsurface plant root-knot nematodes. Proceeding of Fla. State Hortis. Society 107, 430-432.

Nico, A. I., Rapport, H. F., Jimenez-Diaz, R. M. and Castillo, P. (2002): Incidence and population density of plant-parasitic nematodes associated with olive planting stocks at nurseries in southern Spain. Plant Dis. 1075-1079.

Nico, A. I., Jimenez-Diaz, R. M. and Castillo, P. (2003): Solarisation of soil in piles for the control of Meloidogyne incognita in olive nurseries in southern Spain. Plant Pathol. 52, 770-778.

Palomares-Rius, J. E, Guesmi, I., Horrigue-Rouani, N., Cantalapeida, C., Liebanas, G. and Castillo, P. (2014): Morphological and molecular characterization of Pratylenchus olea (Nematoda: Pratylenchidae) parasiting wild and cultivated olives in Spain and Tunisia. Eur. J. Pathol. 140, 53-67.

Philis, J. and Siddiqui, M. R. (1976): A list of plant parasitic nematodes in Cyprus. Nematol. Medit. 4, $171-174$.

Sasanelli, N. (2009): Olive nematodes and their control. In: A. Ciancio and K. G. Mukerji (eds): Integrated Management of Fruit Crops and Forest Nematodes. Springer Science + Business Media B. V., Dordrecht, the Netherlands, 275-315.

Sasanelli, N. and D'Abbado, T. (2002): Reaction of olive to Pratylenchus vulnus infections in Italy. Nematol. 4, 259-264.

Sasanelli, N., D’Abbado, T. and Lemos, R. M. (2002): Influence of Meloidogyne javanica on growth of olive cuttings in pots. Nematropica 32, 59-63.

Schrec-Reis, C., Vieira dos Santos, M. C., Marais, M. N., De Santos, M. S., Duyts, H., Freitas, H., Van der Putten, W. H. and Abrantes, I. M. (2010): First record of Helicotylenchus varicaudatus Yuen, 1964 (Nematoda: Hoplolaimidae) parasitizing Ammophila arenaria (L.) Link in Portuguese coastal sand dunes. Phytopathol. Medit. 49, 212-226.

Troccoli, A., Lamberti, F. and Greco, N. (1992): Pratylenchus species occurring in Algeria (Nematoda, Pratylenchidae). Nematol. Medit. 20, 97-103.

Tzortzakakis, E. A. and Trudgill, D. L. (2005): A comparative study of the thermal time requirements for embryogenesis in Meloidogyne javanica and Meloidogyne incognita. Nematol. 7, 313-315. 